\title{
EVALUATION OF RIGID PAVEMENTS BY DEFLECTION APPROACH
}

\author{
Akshay Gadiya ${ }^{1}$, Sagar Bhor ${ }^{2}$, Parimal Parchure ${ }^{3}$, Ankkit Bafna ${ }^{4}$ \\ ${ }^{1}$ Department of Civil Engineering, Sinhgad College of Engineering, Vadgaon (Bk.), Pune-41, Maharashtra, India \\ ${ }^{2}$ Department of Civil Engineering, Sinhgad College of Engineering, Vadgaon (Bk.), Pune-41, Maharashtra, India \\ ${ }^{3}$ Department of Civil Engineering, Sinhgad College of Engineering, Vadgaon (Bk.), Pune-41, Maharashtra, India \\ ${ }^{4}$ Department of Civil Engineering, Sinhgad College of Engineering, Vadgaon (Bk.), Pune-41, Maharashtra, India
}

\begin{abstract}
Since 1951 there has been a sevenfold increase in the Indian road network while the traffic has increased 120 times. This leads to the deterioration of the surface of the pavements. Deterioration of pavements may be functional or structural in nature. Evaluation and timely assessment of pavement condition will help to judge the necessary steps to be taken to improve pavement conditions. Pavement surface deflection measurements are one of the primary means of evaluating a flexible pavement structure. 'Benkelman Beam Deflection (BBD) Technique is used to find out the characteristic deflection for flexible pavement. The testing and analysis by BBD technique finally provides us with overlay thickness in terms of Bituminous Macadam.

The use of BBD technique may not be only limited to evaluate flexible pavements. Evaluation of newly constructed rigid pavements on the basis of Load Transfer Efficiency of dowel bars gives an idea of the overall performance. The accuracy of evaluating load transfer efficiency (LTE) of joint is important to estimate whether the dowel is disabled or not. The ratio of the edge deflection of unloaded slab to the edge deflection of loaded slab is used as index to evaluate LTE of joint. The objective of this paper is to find out the utility of Benkelman Beam Deflection Test on rigid pavements. In this paper based on the known deflection relationship between loaded and unloaded slab calculated with the help of two Benkelman beams which is a technique generally used to determine the overlay thickness for flexible pavements. A rigid pavement road stretch (Swami Vivekanand Road) constructed 2 years ago in Pune city was evaluated using BBD technique. Deflections measured on slabs (loaded slab and unloaded slab) across the dowel bars would give a measure of the load transfer efficiency of the dowel bars.
\end{abstract}

Keywords: Rigid Pavement, Benkelman Beam Deflection Test, Load Transfer Efficiency

\section{RIGID PAVEMENTS}

Rigid Pavements are those which possess noteworthy flexural strength or flexural rigidity. The rigid pavements are generally made of Portland cement concrete and are therefore called as CC pavements. Most common materials used for design and construction of rigid pavements in high quality plain cement concrete meant for pavement , generally called Pavement Quality Concrete(PQC). The CC pavement slabs made of $\mathrm{PQC}$ are generally expected to sustain up to $45 \mathrm{~kg} / \mathrm{cm} 2$. In rigid pavements the stresses are not transferred from grain to grain to the lower layers as in the case of flexible pavement layers.

The rigid pavements have slab action and are capable of transmitting the wheel load stresses through a much wider area below the pavement slab. The main point of difference in the structural behaviour of rigid pavement as compared to flexible pavement is the critical condition of stresses in rigid pavement is the maximum flexural stresses occurring at certain critical conditions of CC slab duration to combined action of wheel load and temperature stresses. The design life of $\mathrm{CC}$ pavement is 30 years or higher period.

\subsection{Structure of Rigid Pavement}

A typical rigid pavement or $\mathrm{CC}$ pavement structure and the component layers are shown in Figure 1 Thus the CC pavement is supported by a prepared soil sub grade, sub base and the base course. The $\mathrm{CC}$ pavement slab has to withstand flexural stresses caused by moving traffic loads and warping action of the slab due to daily variation in temperature.

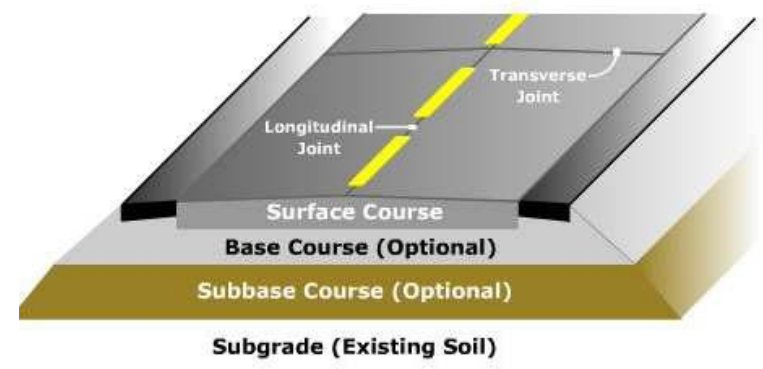

Fig -1: Structure of Rigid Pavement Source - http://www.civil.iitb.ac.in/

\subsection{Joints in Rigid Pavements}

Joints form an important component of CC pavement and they have important functions to perform. Different types of joints are provided in $\mathrm{CC}$ pavements. Different types of joints are provided in $\mathrm{CC}$ pavements to relive part of the stresses developed due to the temperature variations in the slabs. The joints are broadly classified as: 


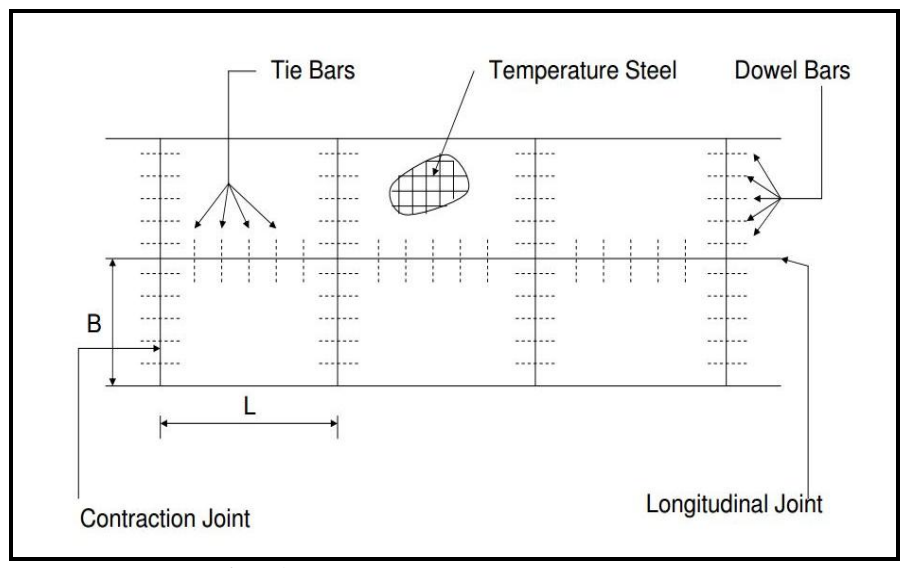

Fig -2: Joints in Rigid Pavement

\subsubsection{Longitudinal Joints}

Shrinkage crack generally develop in CC pavements slabs supported on the base course during the initial period of curing, when the length or width of slabs exceed 4.5 to 5.0 $\mathrm{m}$. hence for pavement widths greater than $4.5 \mathrm{~m}$ there is need to provide longitudinal joints.

The longitudinal joints functions as

1. Contraction joints and prevents development of additional shrinkage cracks in the longitudinal direction

2. Warping joints and relives part of warping stresses.

Tie bars are placed along the longitudinal joints of $\mathrm{CC}$ pavements in order to prevent opening up the longitudinal joints in due course.

\subsubsection{Transverse Joints}

\subsubsection{Contraction Joints}

Shrinkage cracks are developed in CC pavements at certain depth. Therefore Contraction joints are formed by cutting grooves of width not less than $3 \mathrm{~mm}$ and depth 25 to $30 \%$ of pavement thickness so that the fine shrinkage crack is formed below each groove at the weakened section, during the initial period of curing of the pavement. These dummy grooves are provided at interval 4 to $5 \mathrm{~m}$ or less than that so the shrinkage cracks develop along these predetermined sections only. Closely placed contraction joints relive part of warping stresses developed due to temperature differential between the top and bottom of CC pavement slab.

\subsubsection{Expansion Joints}

During the hot season of the year, CC pavement slabs expand due to overall increase in temperature of pavement. Similarly, during cold season they contract. Therefore in order to accommodate variation in length of CC slabs, expansion joints are provided in the transverse direction of CC pavements at fairly long intervals, after number of contraction joints. The expansion joints are formed as through joints across the full depth of slab with about 20 $\mathrm{mm}$ gap between two slabs. Thus the CC pavements slab is separated across the expansion joint and therefore there in no load transfer across expansion joints, resulting in weak cross-section of $\mathrm{CC}$ pavement across the joints. In order to strengthen location of these $\mathrm{CC}$ pavement slabs and to provide load transfer across the expansion joint, suitable steel Dowel Bars are designed and installed.

\subsubsection{Construction Joints:}

During the construction of CC pavements when the concreting work is stopped at the end the day or concrete paving is suspended due to any other reason, a construction joint is formed.

\section{DOWEL BARS}

Expansion joints and Construction joints are formed as through joints across the full depth of the slab. A small gap of about $20 \mathrm{~mm}$ is provided at expansion joint to allow expansion of long $\mathrm{CC}$ pavement slabs during summer seasons. This gap or joint width helps to relieve the Compressive Stresses during expansion and also helps to prevent buckling of the slab near joint. Steel Dowel bars are embedded halfway during construction at specified in order to strengthen these weak locations and to provide desired load transfer to the adjoining slab across the joint.

The dowel bar systems are designed such that a group of dowel bars can transfer $40 \%$ of the design axle load, across the joint to the adjoining slab. Thus, deflections measured on slabs (loaded slab and unloaded slab) across the dowel bars would give a measure of the load transfer efficiency of the dowel bars.

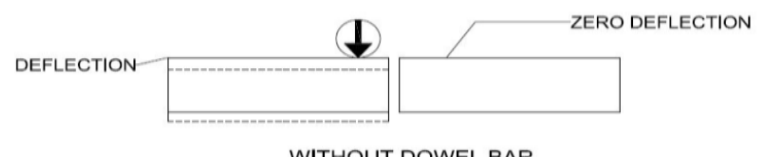

WITHOUT DOWEL BAR

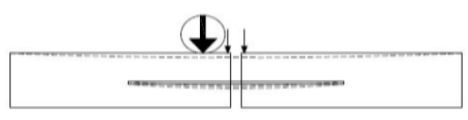

WITH LOAD TRANSFER DOWEL BAR

Fig -3: Dowel bar System

\section{BENKELMAN BEAM DEFLECTION TEST}

Benkelman Beam is a very simple apparatus and it is commonly used for measuring the surface deflection of a pavement under standard loading conditions. While using a Benkelman Beam for measuring the deflections, the load that is applied is either static or creep loading. Although many devices have been invented to measure deflection, the Benkelman Beam is the first really simple device for the highway work, according to engineer Benkelman. Benkelman Beam Deflection (BBD) technique is a popular method due to its simplicity \& low cost. 


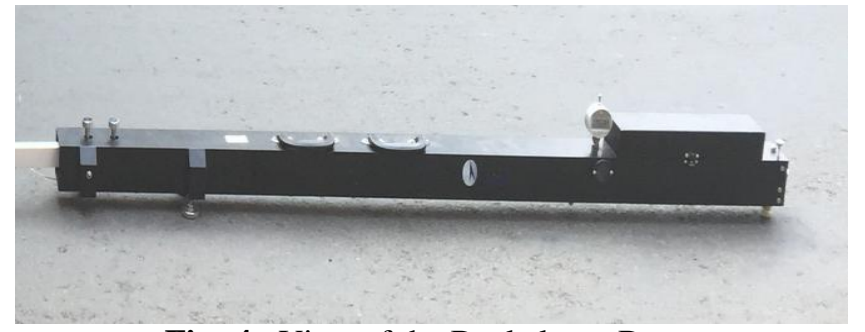

Fig -4: View of the Benkelman Beam

\subsection{Equipment used in the Survey}

- Thermometer

- Auger

- Glycerol

- Truck

- Benkelman Beam

- Dial gauge

- Tape

\subsection{Data Required}

a) Temperature data: The standard temperature for doing the experiment is $35^{\circ} \mathrm{C}$. Since it is not possible to conduct the test at the standard temperature, a correction factor has to be applied for the deflection. The correction factor is determined by knowing the temperature at the time of the survey.

b) Soil data: Deflection measurements should be made during the monsoons when the pavement is in its weakest condition. Hence a correction for seasonal variation has to be applied for the deflection which is a function of the soil sub grade.

The data required is:

- Average annual rainfall in that area

- Soil classification: sandy / gravelly, clayey with low plasticity and clayey with high plasticity.

- $\quad$ Field moisture content. Hence the soil tests that have to be conducted are

- Moisture content test and Atterberg's limit tests (for Determination of PI value).

\subsection{Truck Specifications for Conducting the Test}

a) Rear axle weight of the truck $=8170 \mathrm{~kg}$

b) Tyre pressure $=5.6 \mathrm{~kg} / \mathrm{cm} 2$

c) Spacing between the tyre walls $=30-40 \mathrm{~mm}$.

\subsection{Procedure}

Procedure as per IRC 81 was followed to determine the initial, intermediate and final deflection on the loaded and unloaded slab for edge loading.

1. The point on the pavement to be tested is selected and marked.

2. The dual wheels of the truck are centred above the selected point.

3. The probe of the Benkelman beam is inserted between the duals and placed on the selected point
4. The locking pin is removed from the beam and the legs are adjusted so that the plunger of the beam is in contact with the stem of the dial gauge. The beam pivot arms are checked for free movement

5. The dial gauge is set at approximately $1 \mathrm{~cm}$. the initial reading is recorded when the rate of deformation of the pavement is equal or less than $0.025 \mathrm{~mm} / \mathrm{min}$

6. The truck is slowly driven a distance of $270 \mathrm{~cm}$ and stopped.

7. An intermediate reading is recorded when the rate of recovery of the pavement is equal or less than 0.025 $\mathrm{mm} / \mathrm{min}$

8. The truck is driven forward a further $9 \mathrm{~m}$

9. The final reading is recorded when the rate of recovery of pavement is equal to or less than $0.025 \mathrm{~mm} / \mathrm{min}$

10. Pavement temperature was recorded at least once every hour inserting thermometer in the standard hole and filling up the hole with glycerol.

11. The tyre pressure was checked at two or three hour intervals during the day and adjusted to the standard, if necessary.

\subsection{Correction for Temperature}

Correction for temperature variation on deflection values measured at temperature other than $35^{\circ} \mathrm{C}$ should be $0.01 \mathrm{~mm}$ for each degree centigrade change from the standard temperature of $35^{\circ} \mathrm{C}$. The correction will be positive for pavement temperature lower than $35^{\circ} \mathrm{C}$ and negative for pavement temperature higher than $35^{\circ} \mathrm{C}$.

\subsection{Seasonal Variation Correction}

The deflection values corrected for temperature shall be multiplied by the appropriate values of seasonal correction factors obtained from graph given in IRC 81 to get corrected values of deflection.

Moisture correction factors (or seasonal correction factors) depends on field moisture content, type of sub grade soil and annual rainfall.

\section{BBD TEST ON RIGID PAVEMENT}

Test Overview: Conventionally BBD test is conducted on flexible pavements and it is difficult to follow the same on rigid pavements. With a few modifications, BBD technique was used to analyze a rigid pavement stretch in the mentioned area. We analyzed the rigid pavement to calculate the load transfer efficiency (L. T. E.). To do so we used two Benkelman Beams and placed them on adjacent slabs - one on the loaded slab and another on the unloaded slab, near the joints. When the rear axle load of $8170 \mathrm{~kg}$ moves on the pavement surface, the deflection values on both the beams are noted. The L. T. E. is calculated using the following relation:

\section{T. E. = (Unloaded Slab Deflection / Load Slab Deflection) x 100}




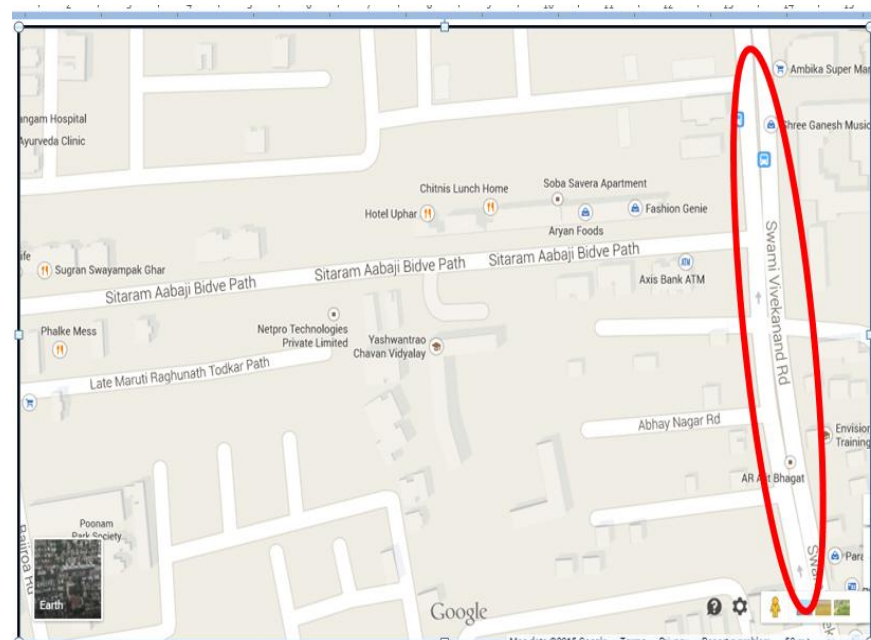

Fig -5: Location Finalized for Benkelman Beam Deflection Testing

Source - Google Maps Screenshot

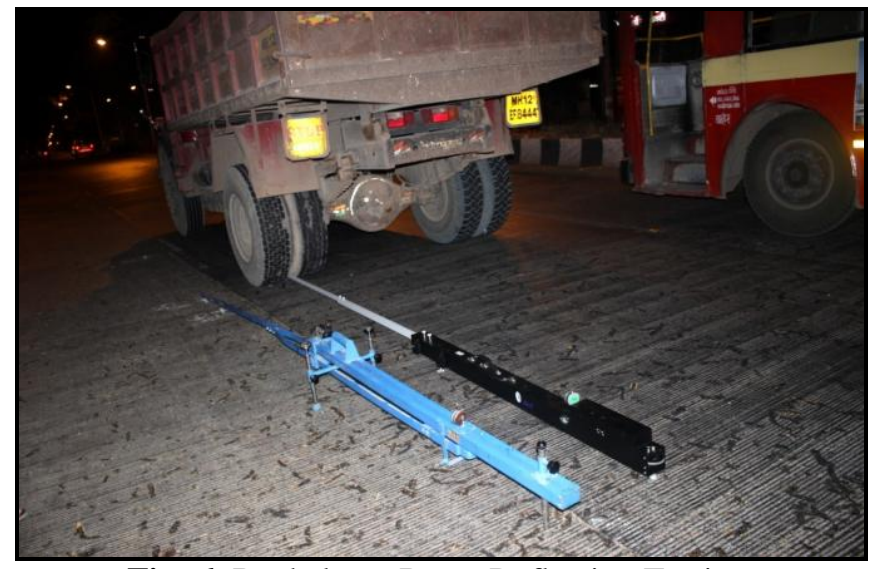

Fig -6: Benkelman Beam Deflection Testing

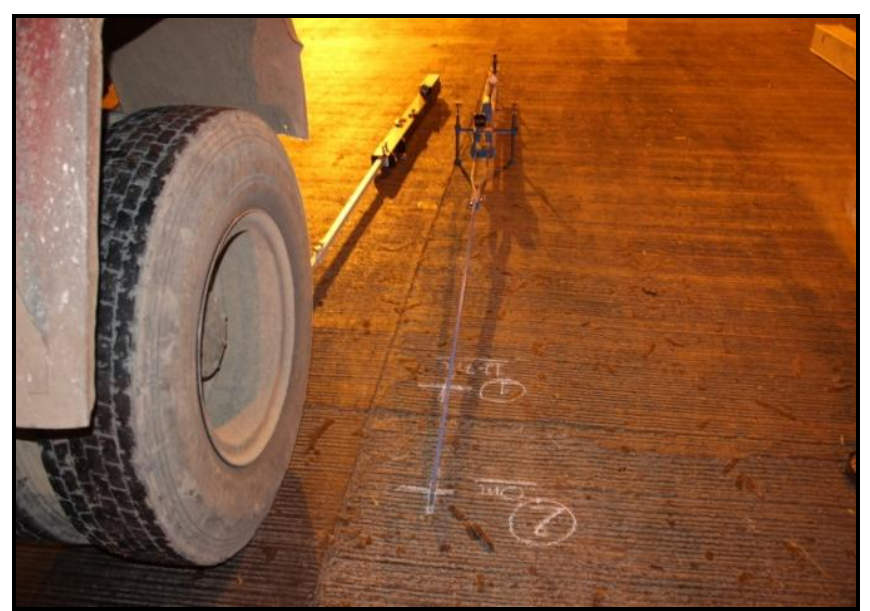

Fig -7: Benkelman Beam Deflection Testing

\subsection{Tests performed on Soil Sample:}

Determination of:

- $\quad$ Moisture Content $=13.76 \%$

- $\quad$ Liquid Limit $\left(\mathrm{W}_{\mathrm{L}}\right)=52.20 \%$

- $\quad$ Plastic Limit $\left(\mathrm{W}_{\mathrm{P}}\right)=42.68 \%$

- $\quad$ Plasticity Index $=\left(\mathrm{W}_{\mathrm{L}}\right)-\left(\mathrm{W}_{\mathrm{P}}\right)=9.52$

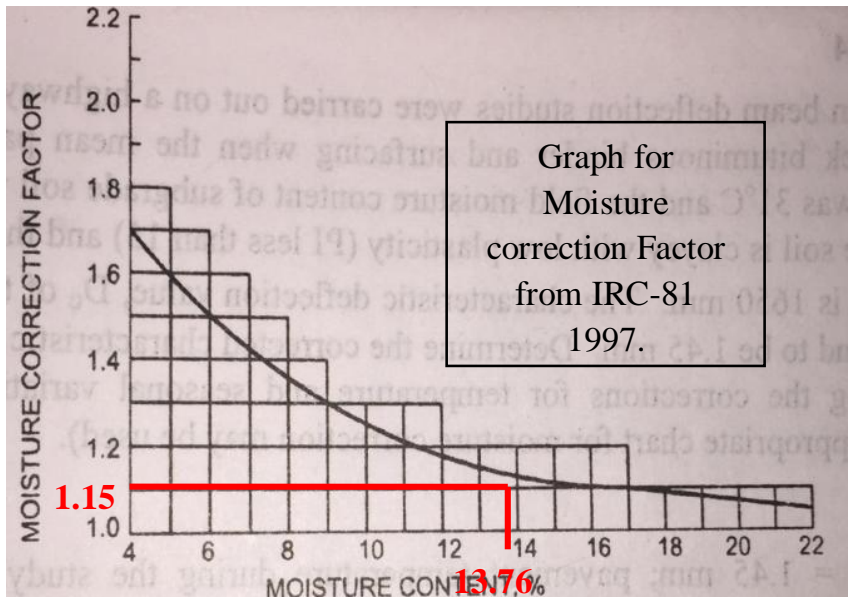

Fig -7: - Moisture Correction factor for clayey sub grade with low plasticity (PI < 15) for low rainfall areas (Annual Rainfall < 1300mm) Source - IRC: 81 - 1997

Load Transfer Efficiency: The load Transfer efficiency calculated based on the deflection measurements shown in annexure are as follows:

\section{T. E. = (Unloaded Slab Deflection / Load Slab Deflection) x 100}

Table -1: LTE Calculations

\begin{tabular}{|c|c|c|c|}
\hline \multirow{2}{*}{$\begin{array}{l}\text { Slab } \\
\text { No. }\end{array}$} & \multicolumn{2}{|c|}{ Corrected Deflection (mm) } & \multirow{2}{*}{$\begin{array}{l}\text { Load Transfer } \\
\text { Efficiency } \\
(\%)\end{array}$} \\
\hline & $\begin{array}{l}\text { Loaded } \\
\text { Slab }\end{array}$ & $\begin{array}{l}\text { Unloaded } \\
\text { Slab }\end{array}$ & \\
\hline 1 & 0.202 & 0.077 & 37.85 \\
\hline 2 & 0.205 & 0.081 & 39.56 \\
\hline 3 & 0.227 & 0.085 & 37.70 \\
\hline 4 & 0.246 & 0.079 & 32.03 \\
\hline 5 & 0.198 & 0.077 & 38.59 \\
\hline 6 & 0.220 & 0.083 & 37.86 \\
\hline 7 & 0.253 & 0.079 & 31.13 \\
\hline 8 & 0.191 & 0.083 & 43.52 \\
\hline 9 & 0.191 & 0.079 & 41.22 \\
\hline 10 & 0.202 & 0.083 & 41.12 \\
\hline
\end{tabular}

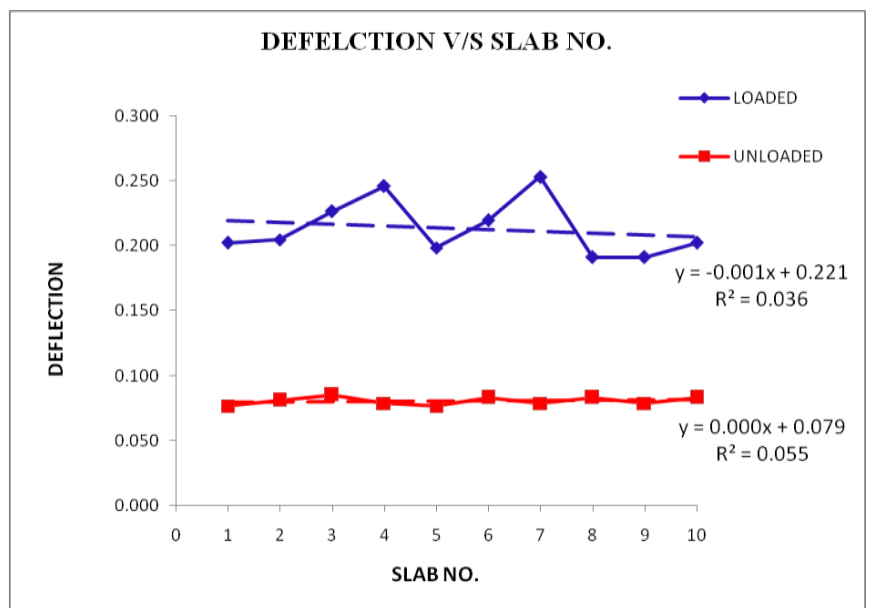

Chart -1: Loaded and Unloaded Slab Deflections 


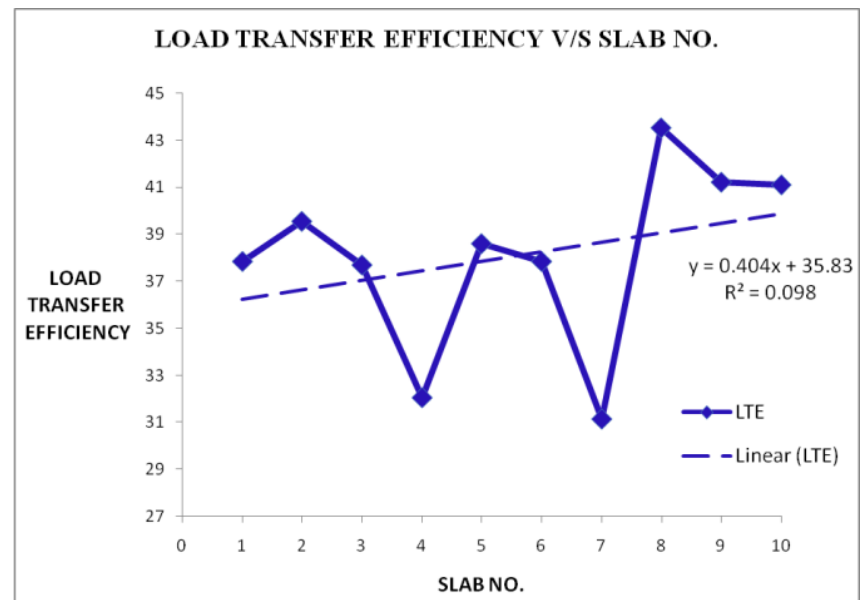

Chart -2: LTE for the slabs of the rigid pavement stretch.

L.T.E. as per Characteristic Deflection:

Loaded Slab $=0.221 \mathrm{~mm}$

Unloaded Slab $=0.082 \mathrm{~mm}$

L. T. E. = (Unloaded Slab Deflection $/$ Load Slab

Deflection) x 100

L. T. E. $=(0.082 / 0.221) \times 100$

L. T. E. $=37.11 \%$

\section{CONCLUSION}

The use of BBD technique may not be only limited to evaluate flexible pavements. Evaluation of newly constructed rigid pavements on the basis of Load Transfer Efficiency of dowel bars gives an idea of the overall performance. The dowel bar systems are designed such that a group of dowel bars can transfer $40 \%$ of the design axle load, across the joint to the adjoining slab. The LTE for Swami Vivekanand Road was found to be $37.11 \%$ across the expansion joints thus, suggesting that the provided dowel bar system was efficient. This was computed using two Benkelman Beams to measure relative deflections of the loaded and unloaded slabs. Therefore it can be concluded that BBD test can be a useful for evaluating the performance of rigid pavements, reliable and alternative tool to Falling Weight Deflectometer (FWD) for the study and performance evaluation of rigid pavements.

\section{ACKNOWLEDGEMENTS}

The undertaking of the project involves team spirit and hard work. Perfect coordination of both of these ultimately leads to success. Things turn out best for the people, who make the best of the way things turn out. The authors are thankful to Asst. Prof. S. S. Kolapkar, Department of Civil Engineering, Sinhgad College of Engineering, Pune who helped us in selection of the project and providing with useful suggestion and essential tips in due time of the project. He has been a true source of moral support and encouragement in situations of adversities.

Last but not the least the authors would like to thank their parents and colleagues for providing constant inspiration, encouragement, support while completing the project.

\section{REFERENCES}

[1] http://www.nhai.org/roadnetwork.html

[2] Partha Chakroborty and Animesh Das. "Principles of Transportation Engineering”, Published by PHI Learning Pvt. Ltd.

[3] D. R. Jundhare, Dr. K. C. Khare and Dr. R. K. Jain. "Development of Correlation between Benkelman Beam Deflection and Falling Weight Deflectometer for Conventional Whitetopping Overlay", Journal for Basic and Applied Scientific Research, Textroad Publications, pp $8725-8731$

[4] S. K. Khanna, C. E. G. Justo and A. Veeraragavan."Highway Engineering", Published by Nemchand and Bros.

[5] D. R. Jundhare, Dr. K. C. Khare; and Dr. R. K. Jain.Civil Engineering Department, Sinhgad College of Engineering, Vadgaon (Bk.), Pune-411041. M. S. India. University of Pune. Study of Edge Stresses and Deflections in Whitetopping Overlay on Winkler

[6] IRC: 81-1997, Guide lines for strengthening of flexible road pavement using benkalman beam deflection. Foundation

\section{BIOGRAPHIES}

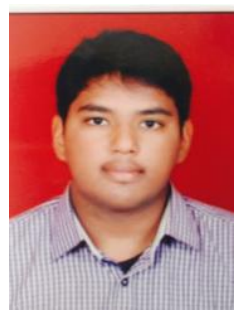

Akshay Gadiya, Final Year, Bachelor of Engineering (Civil), Sinhgad College of Engineering, Pune. Email: aksg221@gmail.com

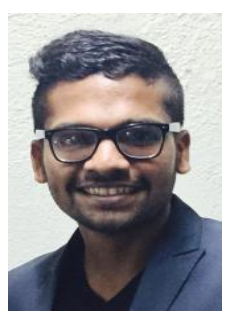

Sagar Bhor, Final Year, Bachelor of Engineering (Civil), Sinhgad College of Engineering, Pune Email: sagar10226@gmail.com

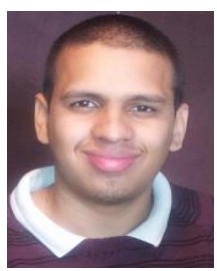

Parimal Parchure, Final Year, Bachelor of Engineering(Civil), Sinhgad College of Engineering, Pune Email: 93.parimal@gmail.com

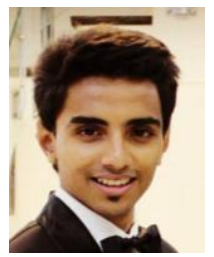

Ankkit Bafna, Final Year, Bachelor of Engineering (Civil), Sinhgad College of Engineering, Pune Email: bafna.ankkit@gmail.com 


\section{ANNEXURE}

\section{A) Loaded Slab}

\begin{tabular}{|c|c|c|c|c|c|c|c|c|c|c|c|c|c|c|}
\hline \multirow[b]{2}{*}{$\begin{array}{l}\text { Sr. } \\
\text { No. }\end{array}$} & \multicolumn{3}{|c|}{ Dial Gauge Reading (mm) } & \multirow[b]{2}{*}{$\mathrm{D}_{\mathbf{0}}-\mathrm{Df}$} & \multirow[b]{2}{*}{ Di-Df } & \multirow[b]{2}{*}{ D } & \multirow{2}{*}{$\begin{array}{l}\text { Temp } \\
\text { eratu } \\
\text { re } \\
\text { Corre } \\
\text { ction }\end{array}$} & \multirow{2}{*}{$\begin{array}{l}\text { Cor } \\
\text { recti } \\
\text { on } \\
\text { for } \\
\text { Seas } \\
\text { onal } \\
\text { Vari } \\
\text { atio } \\
\text { n } \\
\end{array}$} & \multirow{2}{*}{$\begin{array}{l}\text { Corre } \\
\text { cted } \\
\text { Deflec } \\
\text { tion } \\
\text { (xi) }\end{array}$} & \multirow{2}{*}{$\begin{array}{l}\text { Mea } \\
\text { n } \\
\text { Defle } \\
\text { ction } \\
\text { ( б) }\end{array}$} & \multirow[b]{2}{*}{$\begin{array}{cc}(\mathbf{x i} & - \\
б) & \end{array}$} & \multirow[b]{2}{*}{$(\mathbf{x i}-\sigma)^{2}$} & \multirow{2}{*}{$\begin{array}{l}\text { Stand } \\
\text { ard } \\
\text { Devia } \\
\text { tion }\end{array}$} & \multirow{2}{*}{$\begin{array}{l}\text { Char } \\
\text { acter } \\
\text { istic } \\
\text { Defle } \\
\text { ction }\end{array}$} \\
\hline & $\mathbf{D}_{\mathbf{0}}$ & Di & Df & & & & & & & & & & & \\
\hline 1 & 14.994 & 14.936 & 14.934 & 0.066 & 0.002 & 0.120 & 0.07 & \multirow{10}{*}{1.1} & 0.202 & \multirow{10}{*}{0.214} & -0.011 & 0.00012500 & \multirow{10}{*}{0.007} & \multirow{10}{*}{0.221} \\
\hline 2 & 12.366 & 12.308 & 12.305 & 0.070 & 0.003 & 0.122 & 0.07 & & 0.205 & & -0.009 & 0.00007829 & & \\
\hline 3 & 14.541 & 14.472 & 14.470 & 0.077 & 0.002 & 0.142 & 0.07 & & 0.227 & & 0.013 & 0.00016837 & & \\
\hline 4 & 10.237 & 10.157 & 10.157 & 0.080 & 0.000 & 0.160 & 0.07 & & 0.246 & & 0.032 & 0.00105129 & & \\
\hline 5 & 11.53 & 11.477 & 11.472 & 0.073 & 0.005 & 0.117 & 0.07 & & 0.198 & & -0.015 & 0.00022790 & & \\
\hline 6 & 11.842 & 11.775 & 11.774 & 0.071 & 0.001 & 0.136 & 0.07 & & 0.220 & & 0.006 & 0.00003844 & & \\
\hline 7 & 9.575 & 9.495 & 9.492 & 0.092 & 0.003 & 0.166 & 0.07 & & 0.253 & & 0.040 & 0.00156433 & & \\
\hline 8 & 8.449 & 8.395 & 8.394 & 0.058 & 0.001 & 0.110 & 0.07 & & 0.191 & & -0.022 & 0.00050178 & & \\
\hline 9 & 12.354 & 12.300 & 12.299 & 0.058 & 0.001 & 0.110 & 0.07 & & 0.191 & & -0.022 & 0.00050178 & & \\
\hline 10 & 13.453 & 13.395 & 13.393 & 0.066 & 0.002 & 0.120 & 0.07 & & 0.202 & & -0.011 & 0.00012599 & & \\
\hline & & & & & & & & $\square$ & 2.136 & & $\square$ & 0.00438 & & \\
\hline
\end{tabular}

\section{B) Unloaded Slab}

\begin{tabular}{|c|c|c|c|c|c|c|c|c|c|c|c|c|c|c|}
\hline \multirow{2}{*}{$\begin{array}{l}\text { Sr } \\
\text { No } \\
\cdot\end{array}$} & \multicolumn{3}{|c|}{ Dial Gauge Reading (mm) } & \multirow{2}{*}{$D_{0}-D f$} & \multirow{2}{*}{ Di-Df } & \multirow{2}{*}{ D } & \multirow{2}{*}{$\begin{array}{l}\text { Tem } \\
\text { pera } \\
\text { ture } \\
\text { Cor } \\
\text { recti } \\
\text { on }\end{array}$} & \multirow{2}{*}{$\begin{array}{l}\text { Cor } \\
\text { recti } \\
\text { on } \\
\text { for } \\
\text { Seas } \\
\text { onal } \\
\text { Vari } \\
\text { atio } \\
\text { n }\end{array}$} & \multirow{2}{*}{$\begin{array}{l}\text { Corre } \\
\text { cted } \\
\text { Deflec } \\
\text { tion } \\
\text { (xi) }\end{array}$} & \multirow{2}{*}{$\begin{array}{l}\text { Mean } \\
\text { Deflec } \\
\text { tion } \\
\text { ( б) }\end{array}$} & & \multirow{2}{*}{$(\mathbf{x i}-\sigma)^{2}$} & \multirow{2}{*}{$\begin{array}{l}\text { Stand } \\
\text { ard } \\
\text { Devia } \\
\text { tion }\end{array}$} & \multirow{2}{*}{$\begin{array}{l}\text { Chara } \\
\text { cteristi } \\
\text { c } \\
\text { Deflec } \\
\text { tion }\end{array}$} \\
\hline & $\mathbf{D}_{\mathbf{0}}$ & Di & Df & & & & & & & & & & & \\
\hline 1 & 13.300 & 13.298 & 13.297 & 0.003 & 0.001 & 0.006 & 0.07 & \multirow{10}{*}{1.1} & 0.077 & \multirow{10}{*}{0.081} & -0.004 & 0.00001568 & \multirow{10}{*}{0.001} & \multirow{10}{*}{0.082} \\
\hline 2 & 15.564 & 15.561 & 15.559 & 0.005 & 0.002 & 0.010 & 0.07 & & 0.081 & & 0.000 & 0.00000019 & & \\
\hline 3 & 11.579 & 11.575 & 11.572 & 0.007 & 0.003 & 0.014 & 0.07 & & 0.085 & & 0.005 & 0.00002343 & & \\
\hline 4 & 14.423 & 14.420 & 14.419 & 0.004 & 0.001 & 0.008 & 0.07 & & 0.079 & & -0.002 & 0.00000310 & & \\
\hline 5 & 9.875 & 9.872 & 9.872 & 0.003 & 0.000 & 0.006 & 0.07 & & 0.077 & & -0.004 & 0.00001568 & & \\
\hline 6 & 8.796 & 8.792 & 8.790 & 0.006 & 0.002 & 0.012 & 0.07 & & 0.083 & & 0.003 & 0.00000697 & & \\
\hline 7 & 15.387 & 15.384 & 15.383 & 0.004 & 0.001 & 0.008 & 0.07 & & 0.079 & & -0.002 & 0.00000310 & & \\
\hline 8 & 9.758 & 9.754 & 9.752 & 0.006 & 0.002 & 0.012 & 0.07 & & 0.083 & & 0.003 & 0.00000697 & & \\
\hline 9 & 10.237 & 10.235 & 10.233 & 0.004 & 0.002 & 0.008 & 0.07 & & 0.079 & & -0.002 & 0.00000310 & & \\
\hline 10 & 9.741 & 9.739 & 9.735 & 0.006 & 0.004 & 0.012 & 0.07 & & 0.083 & & 0.003 & 0.00000697 & & \\
\hline & & & & & & & & $\square$ & 0.806 & & $\square$ & 0.00009 & & \\
\hline
\end{tabular}

